VAKANÜVIS- Uluslararası Tarih Araştırmaları Dergisi/ International Journal of Historical Researches, Mart/March 2017, YII/Vol. 2, No. 1 ISSN: 2149-9535

\title{
Tımışvar Sancağı'nda Tımar Rejiminin Teşekkülü ve illk Uygulamalar (1555-1556)
}

Murat Serdaroğlu*

\section{Özet}

Osmanlı Devleti'nde fetihten sonra arazi, mülkiyet ve tasarruf şekillerini belirlemek amacıyla tahrirler yapılırdı. 1552 yılında Tımışvar'ın fethinin ardından, 1554 yılında Tımışvar Vilayeti tesis edilerek arazi tahrirleri yapılmıştır. Bu çalışmada Tapu-Tahrir Defterleri içerisinde 298 numarada kayıtlı ve 1555-1556 tarihli Tımışvar Livası Tımar İcmâl Defteri'ne göre dirliklerin dağılımı incelenmiştir. İncelememiz sonucunda gelirlerin \% $57,9^{\prime}$ unun has, \%14,6'sının zeâmet ve \%27,5'inin ise tımar olarak tevcih edildiği tespit edilmiştir.

Anahtar Sözcükler: Tımışvar, tımar, kale, Osmanlı, dirlik

\section{The Formation of the Timar Regime and Its First Practices in Tımışvar Sanjak (1555-1556)}

\begin{abstract}
In the Ottoman Empire, after the conquest, registration books was shaped to determine the forms of land, property and savings. After the conquest of Tımışvar in 1552, the province of Tımışvar was established in 1554 and the lands were registered on the books. In this study, the distribution of dirlik according to Tımısvar Livası Tımar İcmâl Book registered in 298 of the Register of Tapu-Tahrir and dated back to the years of 15551556 was examined. As a result of the study, it was determined that $57.9 \%$ of the revenues were reserved as has , $14.6 \%$ of the revenues were reserved as zeamet and $27.5 \%$ of the revenues were delivered as timar.
\end{abstract}

Okutman, Ömer Halisdemir Üniversitesi, Atatürk İlkeleri ve İnkılap Tarihi Bölümü, Niğde, (Sakarya Üniversitesi, Sosyal Bilimler Enstitüsü, Tarih Anabilim Dalı, Doktora Öğrencisi), muratsrl@gmail.com. (Makale gönderim tarihi: 02.02.2017, makale kabul tarihi: 23.03.2017)

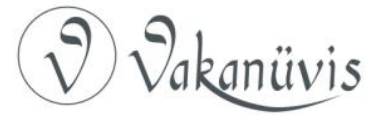


Keywords: Tımışvar, timar, castle, Ottoman, dirlik

\section{Giriş}

Tımışvar $^{1}, 1551$ yılında Sokullu Mehmed Paşa tarafından başarısız kuşatmanın ardından, 1552 yılında Kara Ahmed Paşa tarafından fethedilerek Osmanlı hâkimiyetine girmiştir. ${ }^{2}$ Fetih sonrası bir süre Budin Vilayeti'ne sancak olarak bağlanan Tımışvar, Erdel ve Bosna'yı korumak amacıyla 1554 yılında merkezi Tımışvar olan müstakil bir vilayet haline getirildi $^{3}$ ve ilk beylerbeyliğine Gazi Kasım Paşa atanmıştır. ${ }^{4}$ Gazi Kasım Paşa 1555 yılında Osmanlı hükümetine gönderdiği arzda sınırdaki gelişmeleri daha rahat takip edebilmek amacıyla vilayetin merkezini Lipova'ya taşımak istemiştir. Merkezi hükümetin bu fikri kabul etmesi üzerine 2 yıllık bir süre zarfında Lipova, Tımışvar Vilayeti'nin paşa sancağı olmuştur. Fakat beylerbeyleri (Mîr-i Mîran) Tımışvar'da ikamet ettiği için, yaklaşık 2 yıl sonra vilayetin merkezi yeniden Tımışvar olarak değiştirilmiştir. ${ }^{5}$

Osmanlı Devleti'nde en büyük idarî birimin karşılığı olan eyalet veya vilayetler ${ }^{6}$ sancak veya livalara bölünmüştür. Bu çalışmada Tımışvar Vilayeti'nin aynı adlı "Paşa Sancağı"ndaki dirlikler

\footnotetext{
${ }^{1}$ Tımışvar, Romen dilinde Timeşiara, Slav dillerinde Temsvar, Macarca da Temesvar, Almanca da Temeshburg ve Osmanlı kaynaklarında Tımışvar/Temeşvar/Tamışvar şeklinde adlandırılır. Bkz. Mihai Maxim, "Tımışvar", DiA, Cilt 41, İstanbul, 2012, s. 94.

2 Tımışvar'ın Fethi ile ilgili bkz. M. Feridun Emecen" Sultan Süleyman Çağı ve Cihan Devleti", Türkler, C.9, Ankara, 2002, s. 512; aynı yazar, Osmanlı Klasik Çağında Siyaset, Timaş Yayınları, İstanbul, 2009; Peçevi İbrahim Efendi, Peçevi Tarihi, Hazırlayan: Bekir Sıtkı Baykal, Kültür Bakanlığı Yayınları, Cilt I, Ankara, 1981; Sadık Müfit Bilge, Osmanlı'nın Macaristanı, Kitabevi Yayınları, İstanbul, 2010.

${ }^{3}$ Ahmed Akgüzdüz, Osmanlı Kanunnameleri ve Hukuki Tahlilleri, V.Kitap, II. Kısım, İstanbul, 1992, s. 266.

${ }^{4}$ Peçevi Ibrahim Efendi, Peçevi Tarihi, Hazırlayan: Bekir Sıtkı Baysal, Kültür Bakanlığı Yayınları, C. I, Ankara, 1981, s. 208.

${ }^{5}$ Pal Fodor, "Das Wilajet von Temeschwar zur Zeit der osmanischen Eroberung", Südost-Forschungen, 55 (1996), s. 30.

${ }^{6}$ Halil İnalcık, "Eyalet", DiA, Cilt 11, İstanbul, 1995, s. 548.
}

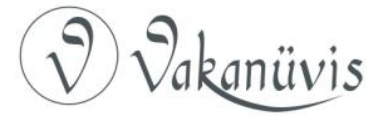


incelenmiştir. ${ }^{7}$ Çalışmamızda ilk olarak tımar sistemi hakkında kısa bilgi verildikten sonra, tımar sisteminin unsurları olan has, zeamet ve tımar olarak dağıtılan dirliklerin miktarı, tasarruf sahipleri ve görevleri incelenecektir.

\section{Tımar Sistemi ve Dirlikler}

Devlet adına çalışan görevlilerin hazineden para ödeme biçimi yerine, görevleri karşılığı, yıllık hesabıyla devlet adına raiyyetten belli vergi ve resimleri kendi hesaplarına toplama usulüne tımar sistemi denilmektedir. 8 Barkan tımarı, "Osmanlı imparatorluğunda geçimlerine veya hizmetlerine ait masrafları karşılamak üzere bir kısım asker ve memurlara, muayyen bölgelerden kendi nâm ve hesaplarına tahsili selâhiyeti ile birlikte tahsis edilmiş olan vergi kaynaklarına ve bu arada bilhassa defter yazılarındaki senelik geliri 20.000 akçeye kadar olan askeri dirliklere verilen isim" ${ }^{\prime \prime}$ olarak tanımlamaktadır.

Osmanlı Devleti'nde tımar sisteminin uygulandığı vilayetlerde nüfus ve vergi gelirlerini tespit etmek amacıyla arazi tahrirleri yapılırdı. Tahrirlerin yapılmasının amacı, vilayetlerdeki gelir kaynaklarını tespit ederek, bunları devlet görevlilerine hizmet karşılığı maaş olarak dağıtılmaktaydı. ${ }^{10}$ Tımar teşkilatı fonksiyonlarına göre üç ayrı kategoriye ayrılmakta, bunlarda kendi içinde alt kategorilere bölünmektedir. Birinci sırada Has gelmektedir. Has, Havâss-ı Hümâyûn

\footnotetext{
${ }^{7}$ inalcık, a.g.m., s. 549; Tımışvar Beylerbeyliğinin, 1566 yılına kadar sancakları: Tımışvar, Lipova, Arad, Çanad ve Beşkelek'ti. Bkz. Fodor, Pal, Das Wilajet von Temeschwar zur Zeit der Osmanischen Eroberung, Südost forschungen, Vol.55, (1996) s. 29; 1568-1574 yıllarında Tımışvar Beylerbeyliği 8 sancağa sahiptir. Tımışvar, Lipova, Vidin, Alacahisar, Çanad, Göle maa Arad, Modova ve Pankota. bkz: i. Metin Kunt, Sancaktan Eyalete 1550-1650 Arasında Osmanlı Ümerası ve il Idaresi, Boğaziçi Üniversitesi Yayınları, İstanbul, 1978, ss. 134-135.

${ }^{8}$ Mustafa Akdağ, Türkiye'nin iktisadî ve Iç̧timaî Tarihi, Yapı Kredi Yayınları, İstanbul, 2010, s. 572.

9 Ömer Lütfi Barkan, "Timar", İslam Ansiklopedisi, C. XII/I, İstanbul, 1979, s. 286.

${ }^{10}$ Fatma Acun, "Klasik Dönem Eyalet Idare Tarzı Olarak Timar Sistemi ve Uygulaması”, Türkler, Cilt 9, Ankara, 2002, s. 902; Çalışmamıza konu olan Tımışvar Sancağı 1554 yılında tahriri tamamlanmıştır. Bkz. BOA. TT. 290.
}

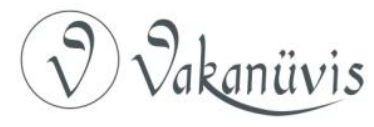


ve Havâss-ı Vüzerâ olarak iki kısımdır. Havâss-ı Hümâyûn prensipte padişaha ait gibi görünse de kapıkullarının giderleri, teçhizatları ve sarayın masrafları buradan karşılanmaktaydı. Bu yüzden en zengin ve en güvenilir gelir kaynakları bu kategori için tahsis edilmişti. Havâss-ı Vüzerâ hükümet üyeleriyle vilayet yöneticileri, sancakbeyleri veya beylerbeyleri için ayrılmıştı. ${ }^{11}$

Hastan sonra dirlik miktarına göre zeâmet gelmektedir. Köylerin ve mezraların yıllık vergi gelirlerin en az yirmi bin akçeden başlayarak herhangi bir kimseye verilmesine zeâmet adı verilir. Zeamet yirmi bin ile yüz bin akçelik geliri olan bir toprak dirliğidir. ${ }^{12}$ Zeametler derece olarak daha düşük memurlara tahsis edilen toprak dirliğidir. ${ }^{13}$

Genel olarak zeâmetler 20.000 akçe ile 100.000 akçe arasında tanımlanmış olsa da arşiv kayıtlarında, 20.000 akçeden daha az zeâmetler ile 100.000 akçeden daha fazla zeâmetlere de rastlanılmaktadır. Bu durum Tımışvar Sancağı için de geçerlidir. 157374 yılına ait bir kayda göre Muharrem Bey adında bir zaîm 102.797 akçelik bir zeâmete sahipti. ${ }^{14}$ 1582-83 yılına ait kayıtta Ali Bey adında bir zaîm 102.767 akçe zeâmeti tasarruf etmekteydi. ${ }^{15}$ Tımışvar Sancağı'nda 20.000 akçenin altındaki zeametler için de örnek vermek mümkündür. 1582-83 tarihli kayda göre Tımışvar Sancă̆ı'nda 18.000 akçelik zeâmete tasarruf eden Hüseyin adındaki zaîme yararııı̆ından dolayı 5.000 akçe gelir ilhak olunarak zeâmeti 23.000 akçeye çıkarıldığı görülür. ${ }^{16}$

Dirlik dağıtımının en alt basamağında Osmanlıların toprak sistemine adını veren tımar yer almaktadır. Sofyalı Ali Çavuş ve Ayn-ı Ali Efendi tımarı "yıllık yirmi binden bir akçe eksik olsa ana zeamet dinilmez, belki

\footnotetext{
${ }^{11}$ Halil İnalcık, "Timar", DiA, C.41, İstanbul, 2012, s. 169.

${ }^{12}$ Sofyalı Ali Çavuş Kanunnamesi, "Osmanlı İmparatorluğunda Toprak Tasarruf Sisteminin Hukuki ve Mali Müeyyede ve Mükellefiyetle", Haz. Midhat Sertoğlu, ï̈. Fen-Edebiyat Yayınları, No:26, İstanbul, 1992, s. 79; IIlhan Şahin, "Tımar Sistemi Hakkında Bir Risale", iÜ, TD, s. 32, İstanbul, 1979, s. 930.

${ }^{13}$ Lajos Fekete, Macaristan'da Türklerin Mülk Sistemi, Çeviren: M. Tayyib Gökbilgin, İstanbul Üniversitesi Tarih Dergisi, Sayı 16, (1961), s. 30.

${ }^{14}$ BOA. TT. 552. s. 14.

${ }^{15}$ BOA. TT. 674. s. 10.

${ }^{16}$ BOA. TT. 674. s. 26.
}

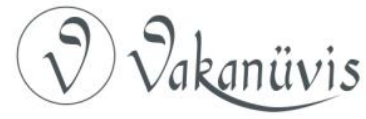


tımar dirler, zira tımarın ekser haddi on dokuz bin dokuz yüz doksan dokuzdur" ${ }^{17}$ şeklinde tarih etmektedirler.

Kanuni dönemine kadar Tımar tevcihleri merkezden yapılmakta idi. Bu dönemde beylerbeyine küçük tımarları tahsis etme yetkisi verildi. Büyük tımarların tevcihi ise, beylerbeyinin İstanbul'a teklifi üzerine merkezde yapilıyordu. Beylerbeyileri veya sancakbeylerinin tavsiyesi ve Divan-ı Hümayun'un uygun görmesi neticesinde tımar sahibi olacak şahsa bir berat verilmekte idi. Beylerbeyinin kendi beratı ile tahsis ettiği tımarlara tezkeresiz tımar, bir tezkire ile merkeze teklif ettiği tımarlara tezkereli tımarlar denilmekteydi. ${ }^{18}$ Tımışvar Sancağı'nda tımarların birçoğu yararlılık gösterenlere Tımışvar Beylerbeyi'nin arzıyla merkezi hükümet tarafından tımar tevcihi yapılmıştır. ${ }^{19}$ Bunlar tezkereli tımarlar grubuna girmektedir.

Tımar alan sipahinin yerine getirmesi gereken çeşitli görevleri vardır. Sefere memur oldukları vakit seraskerin emrinde cebelileri ile birlikte yoklamaları yapılırdı. Sefere katılmamaları halinde sipahiler hakkında işlem başlatılırdı. ${ }^{20}$ Mesela; 21 Muharrem 972 tarihli hükme göre Boğdan seferine tayin olunan Tımışvar Eyaleti'ne bağlı zeamet ve tımar sahiplerinin sefere eda olanların ve sefere emir olunup mevcut olmayanların isimleri ve tımarları ile yazılıp Südde-i Saâdete irsal olunması hakkında yasal işlem başlatılmıştır. ${ }^{21}$

Sipahiler dirlikleri oranında sefere teçhiz edip, toplanma yerine cebelileri getirmek zorundaydılar. ${ }^{22}$ En fazla dirlik alan has sahipleri her 5.000 akçe gelir için bir cebeli çıkarmaya mecburdurlar. Zeamet sahiplerinin bu mükellefiyeti 5.000 akçede bir cebeli, Tımar sahiplerine gelince, bunlar kılıç denilen ve devletin her eyaletine göre miktarı

\footnotetext{
${ }^{17}$ Şahin, a.g.m., s. 930, Soyfalı Ali Çavuş, a.g.m., s. 79.

${ }^{18}$ Acun, a.g.m., s. 906.

${ }^{19}$ Bkz. BOA. MD. 15, hüküm 256, 713, 1218, 1339; BOA. MD. 25, hüküm 694, 2104.

${ }^{20}$ M. Tayyib Gökbilgin, "Kanûni Sultan Süleyman'ın Timar ve Zeamet Tevcihi ile İlgili Fermanları”, ï̈. Tarih Dergisi, Sayı 22, İstanbul, 1967, s. 36.

${ }^{21}$ Tımışvar Beglerbegisine yazılan 21 Muharrem 972 tarihli hüküm, BOA. MD. 6. hüküm 81.

22 inalcık, "Timar", s. 169.
}

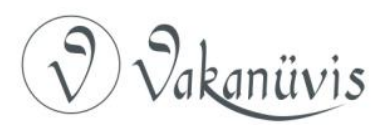


değişen gelirlerinin fazlası için 3.000 akçe de bir cebeli çıkarmakla mükelleftiler. ${ }^{23}$ Burada kılıç tabiri, sipahilik hizmetine ibtidâdan giren herkes için bir başlangıç kadro maaşı olan çekirdek kısmı ifade eder. Bu kısım sipahinin zamanla göstereceği yararlılıklara göre yapılacak terakki zamlarıyla büyümüş olabilirdi. Fakat bu ilaveler ölüm vukuunda hizmete yeni girecek evlatlara aynen ve tamamen intikal etmezdi. ${ }^{24}$ Örnek olarak H. 975 yılında Tımışvar Defterdarına gönderilen hükümde bu hususa dikkat edilerek ibtidâdan verilen tımarların terakkilerinin elinden alınması konusunda uyarılmıştır. ${ }^{25}$ Bunun amacı sipahilerin merkezi otoritenin aleyhine tımar arazilerinin büyütülmesi ve toprağın aile mülkü haline gelmesi önlenmek istenmiştir. ${ }^{26}$

\section{Tımışvar Sancağı'nda 1555-1556 Yılları Arasında Tımar Rejimi}

1554 yılına ait Tımar-icmal defterine göre Tımışvar Sancağı'nda haslar iki kısma ayrılmaktaydı. Bunlardan birincisi Havâss-ı hümâyûn veya Hasshâ-i padişah-ı âlem-penâh denilen padişah hasları, diğeri ise Hâss-ı mîr-i mîran denilen beylerbeyi haslarıydı.

Aşağıdaki Tablo 1'de Padişah haslarının bulunduğu yerler ve gelir çeşitleri incelenecektir.

Tablo 1: 1555/56 Yılında Tımışvar Sancağı'ndaki Padişah Hasları

\begin{tabular}{|l|l|c|}
\hline $\begin{array}{l}\text { Bulunduğu } \\
\text { yer }\end{array}$ & Gelir Çeşitleri & Hasıl \\
\hline $\begin{array}{l}\text { Nefs-i } \\
\text { Tımışvar }\end{array}$ & $\begin{array}{l}\text { Bac-ı bazar, resm-i gümrük, resm-i sergi, } \\
\text { şemhâne, buzhâne, serhâne, beyt-ül- } \\
\text { mâl, Mahsûl-i kira-i dekâkîn, ihzâr ve } \\
\text { ihtisâb }\end{array}$ & 43.512 \\
\hline $\begin{array}{l}\text { Nâhiye-i } \\
\text { Tımışvar }\end{array}$ & Bac-ı bazar ve panayır, bac-ı cisr, 33 Köy & 431.092 \\
\hline
\end{tabular}

${ }^{23}$ Çoşkun Üçok, "Osmanlı Devleti Teşkilatından Tımarlar”, Ankara Üniversitesi Hukuk Fakültesi Dergisi, C. 2, s. 1, Ankara, 1944, s. 542.

${ }^{24}$ Barkan, a.g.m., s. 295.

${ }^{25}$ Tımışvar Defterdarına 28 Ramazan 975 tarihli hüküm, BOA, MD. 7 , hüküm 1151.

${ }^{26}$ Tabakoğlu, a.g.e., s. 192, Barkan, a.g.m., s. 295.

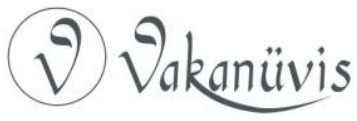




\begin{tabular}{|l|l|c|}
\hline $\begin{array}{l}\text { Nâhiye-i } \\
\text { Çerin }\end{array}$ & Resm-i bellut, 3 Köy & 45.495 \\
\hline Nâhiye-i İktar & Resm-i ubûr, 1 Köy & 15.225 \\
\hline $\begin{array}{l}\text { Nâhiye-i } \\
\text { Şemlik }\end{array}$ & $\begin{array}{l}\text { Bac-ı bazar, resm-i ubûr, Dalyan, 14 Köy } \\
\text { ve 1 Mezra' }\end{array}$ & 292.430 \\
\hline $\begin{array}{l}\text { Nâhiye-i } \\
\text { Boğca }\end{array}$ & Bac-ı bazar, 2 Köy & 120.835 \\
\hline $\begin{array}{l}\text { Nâhiye-i } \\
\text { Modova }\end{array}$ & Dalyan ve 8 Köy & 38.889 \\
\hline $\begin{array}{l}\text { Nâhiye-i } \\
\text { Pançova }\end{array}$ & Bac-ı bazar ve 5 Köy & 178.411 \\
\hline $\begin{array}{l}\text { Nâhiye-i } \\
\text { Çakova }\end{array}$ & Bac-ı bazar ve 9 Köy & 148.469 \\
\hline $\begin{array}{l}\text { Nâhiye-i } \\
\text { Felnak }\end{array}$ & Resm-i ubûr ve 3 Köy & 21.978 \\
\hline Toplam & & $\mathbf{1 . 3 3 6 . 3 3 6}$ \\
\hline
\end{tabular}

1555-1556 yıllarında Tımışvar Sancağı'na ait TT. 298 numaralı Tımar-İcmal defterinde padişah hassı 1.336.336 akçedir. Bu gelirlerin menşelerini incelediğimizde; Tımışvar şehrinin bac-ı bâzâr, resm-i gümrük, resm-i sergi, şemhane, buzhane, serhane, beyt-ül-mâl, mahsul-i kira-i dekâkîn, ihzâr ve ihtisâb gibi yüksek gelir getiren kaynaklar ile nahiyelerdeki bir kısım resimler ve bazı köylerin mahsul gelirlerinden oluşmaktaydı. Gelirlerin sancak içi dağıımına baktığımızda sancak içerisinde 17 nahiyenin ${ }^{28}$ kaydı bulunurken, yalnızca 9 nahiyenin gelirleri padişah hassına ayrılmıştır. Tımışvar Sancağı'nda en fazla gelire sahip olan nahiyeler padişah haslarına ayrılmıştır diyebiliriz. ${ }^{29}$ Padişah hasları sultana ait gibi gözükse de

\footnotetext{
${ }^{27}$ BOA, TT. 298. ss. 1-7.

${ }^{28}$ Tımışvar Sancağı'nın BOA. TT. 290 numaralı tapu tahrir defterine göre nahiyeleri: Tımışvar, Modova, Facet, Suydiya, İktar, Şemlik, Marçina, Bozovar, Bozar, Boğca, Tirgovişta, Fırdına, Felnak, Çakova, Monostor, Çerin ve Pançova'dır.

${ }^{29}$ Bkz. BOA, TT. 290.
}

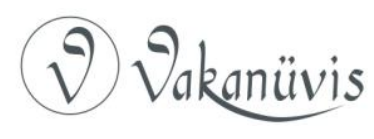


eyaletin veya sancağın masrafları, kalelerin tamiri, yeni kale inşası, yol, köprü yapımı gibi için harcanmaktaydı.

1555/56 yılı Tımar-İımal defterine göre sancak genelinde padişaha ait haslardan başka Tımışvar Beylerbeyine de has tahsis edilmiştir.

Aşağıda Tablo 2'de 1555-1556 yıllarına ait tımar-icmal defterinde yer alan mîr-i mîran hasları belirtilmiştir.

Tablo 2: 1555/56 Yılında Tımışvar Sancağı'nda Mîr-i mîran Hassı

\begin{tabular}{|l|l|c|}
\hline Bulunduğu yer & \multicolumn{1}{|c|}{ Gelir nevi } & Hasıl \\
\hline Tımışvar & $\begin{array}{l}\text { Niyabet ve bâd-ı hevâ, 1 Varoş, } \\
\text { 18 Köy ve 9 Mezra' }\end{array}$ & 173.034 \\
\hline Nahiye-i Iktar & 1 Varoş ${ }^{30}$, 7 Köy & 50.994 \\
\hline $\begin{array}{l}\text { Nahiye-i } \\
\text { Tirgovişta }\end{array}$ & 1 Varoş ve 9 Köy & 34.861 \\
\hline Nahiye-i Şemlik & Nefs-i Şemlik, 6 Köy ve 3 Mezra' & 43.511 \\
\hline Nahiye-i Boğca & 7 Köy & 54.202 \\
\hline $\begin{array}{l}\text { Nahiye-i } \\
\text { Çakova }\end{array}$ & 11 Köy ve 3 Mezra' & 51.989 \\
\hline $\begin{array}{l}\text { Nahiye-i } \\
\text { Marcina }\end{array}$ & Varoş-u Marcina, 14 Köy & 74.188 \\
\hline Nahiye-i Facet & 13 Köy & 55.324 \\
\hline $\begin{array}{l}\text { Nahiye-i } \\
\text { Bozovar }\end{array}$ & 7 Köy & 20.070 \\
\hline Nahiye-i Bozar & Varoş-u Bozar ve 5 Köy & 31.729 \\
\hline Nahiye-i Fırdına & 11 Köy & 40.692 \\
\hline Nahiye-i Felnak & $\begin{array}{l}\text { Varoş-u Felnak, 9 Köy ve 6 } \\
\text { Mezra' }\end{array}$ & 85.861 \\
\hline Diğer & $\begin{array}{l}\text { Resm-i berevât, nısf-ı niyâbet-i } \\
\text { timarhâ-yı sipahiyân ve } \\
\text { mustahfıân-ı liva-i paşa }\end{array}$ & 35.000 \\
\hline Toplam & \begin{tabular}{l}
$\mathbf{7 8 0 . 9 6 6}$ \\
\hline
\end{tabular} & \\
\hline
\end{tabular}

${ }^{30}$ Tımışvar Sancağında Varoş şehir, idari merkez anlamında kullanılmıştır.

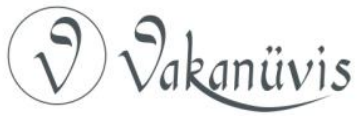


1555/56 tarihli tımar-icmal defterine göre Tımışvar Sancağı'nın toplam gelirlerinin 780.966 akçesi Tımışvar Beylerbeyine has olarak tahsis edilmiştir. Haslar sancakta yer alan 12 nahiyenin şehir ve kır gelirlerinden elde edilmiştir. Tımışvar Beylerbeyi'ne ait hasların sancağın her yerini kapsayacak biçimde serpiştirilmiş olması, beylerbeyinin sancağın her yerini ziyaret ederek sancağın asayiş ve güvenliğinin sağlanması amaçlanmış olabilir. ${ }^{32}$

298 numaralı icmal defterinde beylerbeyine ait hasların kime dirlik olarak verildiği ile ilgili bir kayıt bulunmamaktadır. 1552 yılında beylerbeyi olan Gazi Kasım Paşa Aralık 1555 yılına kadar bu görevde kalmış ve halefi olan Güzelce Rüstem Paşa bu görevi 1555 yılından 1557 yılına kadar yürütmüştür. ${ }^{33}$ Muhtemelen bu defter hazırlanırken Kasım Paşa'nın yerine kimin geçeceği belli olmadığından bu kısım boş bırakılmış olabilir.

Fatih Kanunnamesinde beylerbeylerine 800.000 ile 1.200 .000 akçe arasında has tayin edilmiştir. ${ }^{34} \mathrm{Bu}$ duruma göre Tımışvar Beylerbeyi 780.966 akçe ile kanunnamede belirtilen oranın altında dirliğe sahip olduğu görülmektedir. ${ }^{35}$

Tımışvar Sancağı'nda 1555-1556 yıllarındaki zeâmetlerin durumuna bakıldığında 18 adet zeâmetin olduğu görülmektedir. Aşağıdaki tablo 3'de 1555-1556 yıllarına ait tımar-icmal defterinde yer alan zeâmetler belirtilmiştir.

${ }^{31}$ BOA. TT. 298. s. 7-16.

${ }^{32}$ Acun, a.g.m., s. 902.

${ }^{33}$ Sadık Müfit Bilge, Osmanlı'nın Macaristanı, Kitabevi, İstanbul, 2010, s. 335.

${ }^{34}$ Abdulkadir Özcan, "Fatih'in Teşkilat Kanunnamesi ve Nizam-ı alem için Kardeş Katli Meselesi”, TD, Sayı 33, İstanbul, 1982, s. 47.

${ }^{35}$ Tımışvar Beylerbeyleri 1573-1574 yılında 800.250 akçe; 1582-1583 yılında 806.795 akçe dirliğe sahiptir. bkz. BOA. TT. 552. ss. 11-15; BOA. TT. 674, ss. 69.

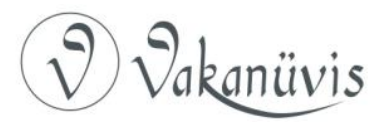


Tablo 3: 1555/56 Yılında Tımışvar Sancağı'nda Zeâmetler

\begin{tabular}{|l|l|l|}
\hline \multicolumn{2}{|l|}{ ZEÂMETLER } & MiKTARI \\
\hline 1 & $\begin{array}{l}\text { Zeâmet be-nâm Mustafa Kethüdâ-i Defter-i } \\
\text { Vilâyet-i Tımışvar }\end{array}$ & 60.764 \\
\hline 2 & $\begin{array}{l}\text { Zeâmet be-nâm Mehmed Çelebi Defterdâr-ı } \\
\text { tımârhâ-i Vilâyet-i Tımışvar }\end{array}$ & 50.575 \\
\hline 3 & $\begin{array}{l}\text { Zeâmet be-nâm Mehmed Mîr-i alem_i } \\
\text { Vilâyet_i Tımışvar }\end{array}$ & 44.170 \\
\hline 4 & Zeâmet be-nâm Ferhad Mîr-alay-ı Liva-i Paşa & 40.437 \\
\hline 5 & Zeâmet be-nâm Mika Voyvoda & 25.000 \\
\hline 6 & Zeâmet be-nâm Ali Kapudân-ı Nehr-i Tisa & 23.318 \\
\hline 7 & $\begin{array}{l}\text { Zeâmet be-nâm Bali Emin Defter-i Vilâyet-i } \\
\text { Tımısvar }\end{array}$ & 21.350 \\
\hline 8 & Zeâmet be-nâm Veli Ağa & 20.264 \\
\hline 9 & Zeâmet be-nâm Ramazan Ağa & 20.325 \\
\hline 10 & Zeâmet be-nâm Kenan Ağa & 20.270 \\
\hline 11 & Zeâmet be-nâm Kaytas Ağa & 20.262 \\
\hline 12 & Zeâmet be-nâm Mustafa Ağa & 20.278 \\
\hline 13 & Zeâmet be-nâm Mustafa Voyvoda & 20.150 \\
\hline 14 & Zeâmet be-nâm Ali Silâhdâr & 20.000 \\
\hline 15 & Zeâmet be-nâm Ali & 20.300 \\
\hline 16 & $\begin{array}{l}\text { Zeâmet be-nâm Dimitri Kulağuz veled-i } \\
\text { Cirlerçik }\end{array}$ & 20.100 \\
\hline 17 & Zeâmet be-nâm Himmet Kethüdâ-i Kasım Paşa & 20.230 \\
\hline 18 & $\begin{array}{l}\text { Zeâmet be-nâm Veli nâzır-ı emvâl-ı sâbık } \\
\text { Vilâyet-i Tımışvar }\end{array}$ & 61.100 \\
\hline Toplamm & $\mathbf{5 2 8 . 8 9 3}$ \\
\hline
\end{tabular}

1555/56 tarihli icmal defterinde 18 adet zeâmet kaydedilmiştir. Bunların toplamı 528.893 akçedir. Zeametler içerisinde en fazla dirliğe

${ }^{36}$ BOA. TT. 298. ss. $17-24$ 
sahip olan Tımışvar Eyaleti'nin Defter Kethüdâsı Mustafa Bey'dir. ${ }^{37}$ Osmanlı Devleti'nde tımar sisteminin uygulandı̆̆ı, fakat hazineye sahip olmayan eyaletlerde merkezden iki defterdâr atanırdı. Bunlar zeamet dağııııını düzenleyen Defter Kethüdâsı, diğeri tımarların dağıtımıyla ilgilenen Tımar Defterdârıdır. ${ }^{38}$ Incelediğimiz defterde Tımışvar Vilayet'nde bu göreve sahip olan Defter Kethüdâsı Mustafa 60.764 akçe, Tımar Defterdarı Mehmet Çelebi 50.575 akçe ile Tımışvar Sancağı'nda en fazla zeâmete sahip olan görevlilerdir.

Osmanlı Devleti'nde sancaktarların ve mehterhanenin başına mîr-i alem denilirdi ${ }^{39}$ Tımışvar Sancağı'nda bu görevi ifa eden Defter Kethüdâsı Mehmet 44.170 akçe dirlik almıştır. Zeâmet verilen kişiler arasında kethüda, kılavuz, silahdâr, kaptan, voyvoda ve ağa gibi yüksek rütbeli devlet görevlileri de yer almaktadır. Tımışvar Sancağı'nda geri kalan zeâmetleri incelediğimizde en az zeâmeti tasarruf eden 20.000 akçe gelire sahip olan Silahdâr Ali Bey'dir. Bu dönemde Tımışvar Sancağı'nda zeâmetler 20.000 akçe ile 25.000 akçe arasında yoğunlaşmaktadır.

Osmanlı Devleti'nde dirlik sisteminin en alt basamağında bulunan tımar, üç kısma ayrılmıştır. Birincisi eşkinci tımarıdır. Incelediğimiz defterde en çok bu türlü tımarlara rastlanılmaktadır. Bunlar sefer zamanı alaybeyinin sancağı altında sefere gitmekle mükelleftir. İkincisi mustahfız tımarıdır. Bunlar mensup olduğu kalenin muhafazasında ve hizmetinde bulunurlardı. Üçüncüsü de hizmet tımarıdır. Bu tımarlar ise serhatlerde bulunan, camilerin imam, hatip gibi vazifelerine ve saray-ı hümayun hizmetlerine tahsis edilmiştir.

\footnotetext{
${ }^{37}$ BOA. TT. 298. s. 17.

38 Rıfat Günalan, Osmanlı Imparatorluğunda Defterdarlık Teşkilatı ve Bürokrasisi, Kayıhan Yayınevi, İstanbul, 2010, s. 34; bkz. Mübühat Kütükoğlu, "Defterdar", DiA, Cilt 9, İstanbul, 1994, ss. 96-96; Ümeradan sonra Defter Kethüdası beylerbeyilik divanında en önemli görevlidir. bkz. Nejat Göyünç, "Osmanlı Devletinde Taşra Teşkilatı (Tanzimata kadar)", Osmanlı, VI, Yeni Türkiye Yayınları, İstanbul, 2010, s. 79.

39 Erhan Afyoncu -Abdülkerim Özaydın, "Mîr-i Alem (Osmanlılar'da)", DiA, Cilt 30, İstanbul, 2005, s. 124.
}

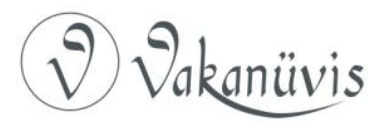


Mesela saraya senede 30.000 sümbül soğanı götürmek, şahin ve çakır denilen kuşları tedarik edenlere ayrılmıştır. ${ }^{40}$

Tımışvar Sancağı'nda has ve zeamet dışında çeşitli tımar çeşitleri olup, bunlar içerisinde çoğunluğu sipahi tımarları ve tımarlı kale muhafızları teşkil etmektedir. Aşağıdaki Tablo 4'de 1555-1556 yıllarında sipahi tımarları gösterilmektedir.

Tablo 4: 1555/56 Yılında Tımışvar Sancağı'nda Tımarlar

\begin{tabular}{|l|l|l|}
\hline \multicolumn{2}{|l|}{ Tımarhâ-i Sipâhiyân } & Miktarı \\
\hline 1 & $\begin{array}{l}\text { Tımar_ı Yusuf Ağa-i azebân-ı Kal'a- } \\
\text { i Belgrad }\end{array}$ & 9.000 \\
\hline 2 & $\begin{array}{l}\text { Tımar_ı Mustafa martalosan-ı } \\
\text { Kal'_a_i Belgrad }\end{array}$ & 6.100 \\
\hline 3 & Tımar-ı Behram bin Yusuf & 9.000 \\
\hline 4 & Tımar Mustafa bin Ali & 6.140 \\
\hline 5 & $\begin{array}{l}\text { Tımar-ı Cafer Mîrahor merdüm-i } \\
\text { Kasım Paşa }\end{array}$ & 10.163 \\
\hline 6 & Tımar-ı Mehmed bin Mîrahor .... & 10.162 \\
\hline 7 & $\begin{array}{l}\text { Tımar-ı Korkud Voyvoda merdüm_i } \\
\text { Kasım Paşa }\end{array}$ & 10.000 \\
\hline 8 & $\begin{array}{l}\text { Tımar-ı Yusuf Voyvoda merdüm-i } \\
\text { Kasım Paşa }\end{array}$ & 5.999 \\
\hline 9 & $\begin{array}{l}\text { Tımar-ı Ibrahim bin Musa } \\
\text { merdüm-i Kasım Paşa }\end{array}$ & 6.050 \\
\hline 10 & Tımar-ı Mehmed Emin Tezkire-i & 10.300 \\
\hline 11 & Tımar-ı Hüseyin Katib & 8.200 \\
\hline 12 & Tımar-ı Mustafa-i Hıram & 6.000 \\
\hline 13 & Tımar-ı Pervane & 6.178 \\
\hline 14 & Tımar-ı Kırk Ahmed & 9.655 \\
\hline 15 & Tımar-ı Mahmud Anatolı & 6.077 \\
\hline 16 & Tımar_ı Şaban ... Ali Paşa & 7.100 \\
\hline 17 & Tımar-ı Ali & 3.000 \\
\hline 18 & Tımar-ı Yusuf & 3.000 \\
\hline 19 & Tımar-ı Ali & 4.000 \\
\hline & & \\
\hline
\end{tabular}

${ }^{40}$ Gökbilgin, a.g.m., s. 35. 


\begin{tabular}{|l|l|l|}
\hline 20 & Tımar-ı ? & 6.000 \\
\hline 21 & Tımar-ı Ahmed & 8.194 \\
\hline 22 & Tımar-ı Cafer ...Hasan Ağa & 5.999 \\
\hline 23 & Tımar-ı Abdullatif & 5.999 \\
\hline 24 & Tımar-ı Mehmed Müslim & 6.000 \\
\hline 25 & Tımar-ı Yusuf & 8.055 \\
\hline 26 & Tımar-ı Mehmed bin Firuz & 6.300 \\
\hline 27 & Tımar-ı Hacı Üveys & 6.200 \\
\hline 28 & Tımar-ı Hüseyin bin Hasan & 5.999 \\
\hline 29 & Tımar-ı Ahmed bin Hüseyin & 5.999 \\
\hline 30 & $\begin{array}{l}\text { Tımar-ı Mustafa Martolosan-ı Kal’a } \\
\text { Kalaça(?) }\end{array}$ & 8.333 \\
\hline 31 & Tımar-ı Radiç veled-i Takovik & 5.000 \\
\hline 32 & Tımar-ı Roşko veled_i Miloş & 6.000 \\
\hline 33 & $\begin{array}{l}\text { Tımar-ı Petko Voyvoda veled-i } \\
\text { Badik }\end{array}$ & 10.000 \\
\hline 34 & Tımar-ı Lukaç veled-i İstroviçik & 5.000 \\
\hline 35 & Tımar-ı Gorag veled-i İstroviçik & 7.000 \\
\hline 36 & $\begin{array}{l}\text { Tımar-ı Larya veled-i Jivkoş Mita } \\
\text { Voyvoda }\end{array}$ & 4.000 \\
\hline 37 & Tımar-ı Yufus (bin) Abdullah & 6.300 \\
\hline 38 & Tımar-ı İskender (bin) Abdullah & 5.000 \\
\hline 39 & Tımar-ı Divane Ali & 2.095 \\
\hline 40 & Tımar-ı Sabo (veled-i) Petre & 8.300 \\
\hline 41 & $\begin{array}{l}\text { Tımar-ı İvan birader-i Dimitri } \\
\text { Çelinçik }\end{array}$ & 5.050 \\
\hline 42 & $\begin{array}{l}\text { Tımar-ı İspatan veled-i Mika } \\
\text { Voyvoda }\end{array}$ & 3.100 \\
\hline 43 & $\begin{array}{l}\text { Tımar-ı Yovan veled-i Mika } \\
\text { Voyvoda }\end{array}$ & 3.053 \\
\hline 44 & Tımar-ı Radol Voyvoda & 8.000 \\
\hline 45 & Tımar-ı Mladan Dyak & 5.000 \\
\hline Yekün & 312.100 \\
\hline
\end{tabular}

${ }^{41}$ BOA. TT. 298. ss. 26-46. 
Tımışvar Sancağı'nda 1555-1556 yıllarında 45 adet tımarın mevcut olduğu görülmektedir. Bu tımarların yekünü 312.100 akçedir. Bu tımarlar içerisinde en yüksek olanı 10.300 akçe tımara sahip tezkireci Mehmed Emin'e, en düşük olanı ise 2.095 akçe ile Divane Ali'ye aittir. Bu dönemde Tımışvar Sancağı'nda tımarlar 5.000 akçe ile 6.000 akçe arasında yoğunlaşmaktadır. Tımışvar Sancağı'nda tımar sahipleri içerisinde sayıları az da olsa birkaç Hıristiyan sipahinin mevcudiyeti dikkatimizi çeker. ${ }^{42}$ Bu durum Osmanlı Devleti'nde, sipahi olabilmek için Müslüman olmanın ön şart olmadığını göstermektedir. ${ }^{43} 45$ tımar içerisinde 12 tımar Hristiyan sipahilere verilmiştir.

Osmanlı Devleti'nde sipahi tımarları haricinde önemli bir yekûne sahip Mustahfızan tımarları bulunmaktadır. Bunların görevi kalenin muhafazasını sağlamaktır. Bunlara hisar eri de denilirdi. ${ }^{44}$ Kalelerde dizdar denilen kumandanlar ve kethüda diye anılan kumandan yardımcıları ile hisar erleri yer almaktadır.

Aşağıda tablo 5'te Tımışvar Sancağı'nda Tımışvar, Çakova, Boğca, Felnak, Facet ve Şemlik kalelerinde görevli kale muhafızları yer almaktadır. ${ }^{45}$ Tımışvar Sancağı'ndaki tımarların ekser çoğunluğu kale mustahfızlarına tahsis edilmiş olan tımarlardır. Bunların dışında da tımarlar olmakla beraber kale mustahfızları için ayrılan tımarlar daha fazladır. Buna göre Tablo $5^{\prime}$ de kale mustahfızları ve miktarları listelenmiştir.

Tablo 5: 1555/56 Yılında Tımışvar Sancağı'nda Kale Muhafızları

\begin{tabular}{|lr|l|l|}
\hline \multirow{2}{*}{ Görev Yeri } & \multicolumn{2}{|l|}{$\mathbf{1 5 5 5 - 1 5 5 6}$ Yılı } \\
\cline { 3 - 4 } & & Adet & Yekün \\
\hline $\begin{array}{l}\text { Cemaat-i Mustahfızan Kal'a-i } \\
\text { Enderun-ı Tımışvar }\end{array}$ & 150 & 256.500 \\
\hline $\begin{array}{l}\text { Mustahfızân-ı Birun-i Kal'a-i } \\
\text { Tımışvar }\end{array}$ & 100 & 171.000 \\
\hline
\end{tabular}

${ }^{42}$ Bkz. Nedim Filipoviç, "Bosna-Hersek Tımar sisteminin İnkişafı", iÜ. Iktisat Fakültesi Mecmuası, C.XV, ss. 154-188.

43 inalcık, Timar, s. 170.

${ }^{44}$ Sofyalı Ali Çavuş, a.g.m., s. 69; Şahin, a.g.m., s. 926.

${ }^{45}$ Makalemizin hacmini aşacağından kalelerdeki görevlilerin toplam sayısı verilmiştir.

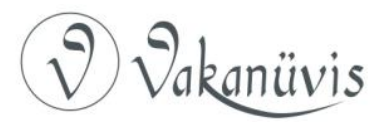




\begin{tabular}{|c|c|c|}
\hline Topcuyân-ı Kal'a-i Tımışvar & 50 & 85.500 \\
\hline Cebeciyân-ı Kal'a-i Tımışvar & 4 & 7.200 \\
\hline Kumbaracıyân-ı Kal'a-i Tımışvar & 5 & 8.600 \\
\hline Toplam & 309 & 528.800 \\
\hline Mustahfızan-ı Kal’a-i Çakova & 13 & 23.100 \\
\hline Mustahfızan-ı Kal'a-i Boğca & 23 & 39.400 \\
\hline Mustahfızan-ı Kal'a-i Felnak & 29 & 49.900 \\
\hline Mustahfızan-ı Kal'a-i Facet & 30 & 51.500 \\
\hline Mustahfızan -ı Kal'a-i Şemlik & 13 & 22.200 \\
\hline $\begin{array}{l}\text { Toplam } \\
\end{array}$ & 417 & 714.900 \\
\hline
\end{tabular}

Timiş Nehri kıyısında yer alan Tımışvar Kalesi ${ }^{46}$ Kal'a-i Enderun ( İç kale) ve Kal'a-i Birun (dış kale) olarak iki kısımdan meydana gelmektedir. 1555-56 yılında İç kalede 150 hisar eri, dış kalede 100 hisar eri yer almaktadır. 1555-56 tarihli deftere göre sadece Tımışvar Kalesi mustahfızlarına verilen tımar miktarı 427.500 akçedir. Mustahfızlardan "serbölük" olanlara 1.800 akçelik tımar, er olan mustahfızlara 1.700 akçelik tımar verilmiştir. Genellikle tasarruf ettikleri tımarlar hisseli tımarlardır. Yani bir köyün tımarı birkaç mustahfız erine pay edilmiştir. ${ }^{47}$ Tımışvar hem sancağın merkezi hem de vilayetin merkezi olduğundan kalabalık bir askeri garnizona sahiptir.

Tımışvar'dan Belgrad'a ve Semendire'ye giden yolun güvenliği sağlamakta olan Çakova, Boğca, Felnak, Facet ve Şemlik kalelerinde kale mustahfızlarının adedi oldukça az sayıdadır. Bu kalelerde görevli 108 adet hisar erine 186.100 akçe tımar verilmiştir.

${ }^{46}$ Gabor Agoston, Osmanlı'da Savaş ve Serhad, Çev. Kahraman Şakul, Timaş Yayınları, İstanbul, 2013, s. 198; Tımışvar şehri, ismini Timiş ırmağından almış ve bu kelime Macarca şehir-hisar anlamına gelmektedir. bkz. Ioan Hategan, Henrik Ottendorf Becstol Temesvarig, (1663), Editura Banatul Timişoara, 2006. ${ }^{47}$ Mesela iki köyün hasılı olan tımar (17.100), Ali (1.800), Gazi Mehmed (1.700), Pervane Abdullah (1.700), Piri Abdullah (1.700), Merdüm Ahmed (1.700), Baki Hüseyin (1.700), Mehmed b.Resul (1.700), Mustafa b.Nasuh (1.700), Hızır b. Hüseyin (1.700) ve Nasuh b. Abdullah (1.700) arasında pay edilmiştir. Bkz. BOA. TT. 298. s.68.

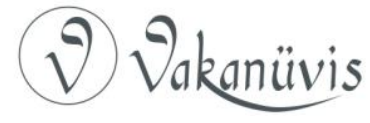




\section{Resim 1.}

\section{Osmanlı Dönemi Tımışvar Kalesi' ${ }^{48}$}

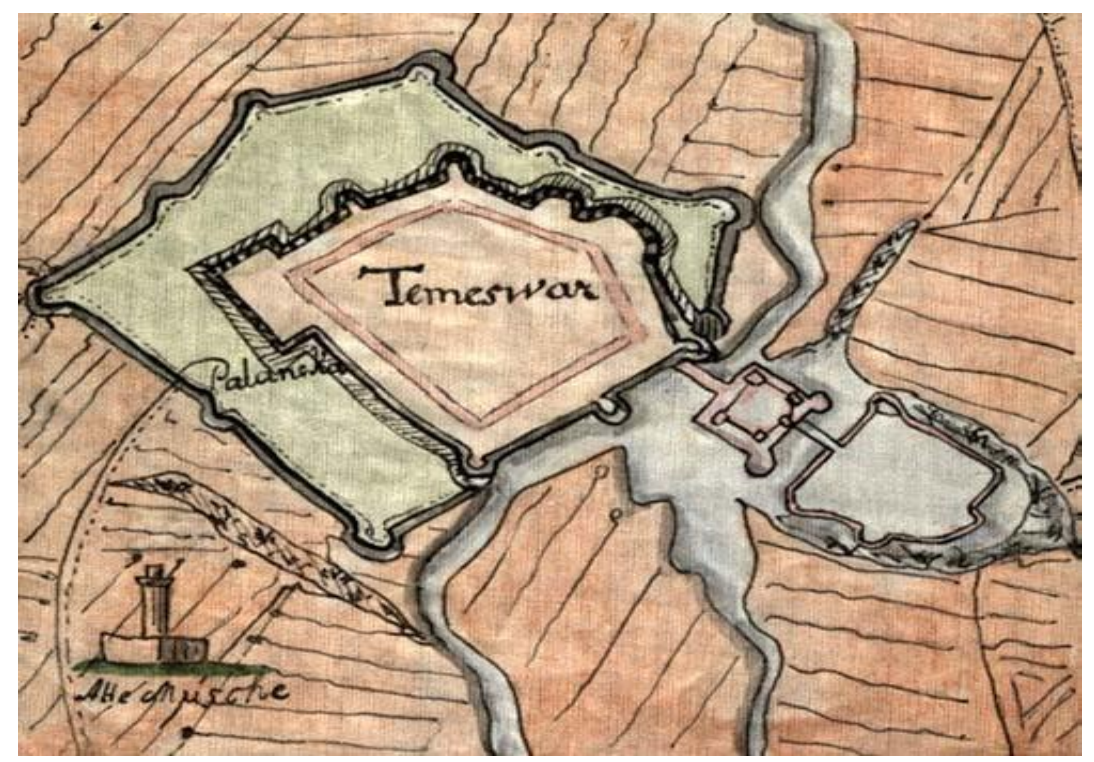

Toprak dirliğinin bir kısmı Osmanlı memleketlerinde bulunan ve derbend diye anılan bazı sarp boğaz ve geçitlerin güvenliğini sağlayan muhafızlara ayrılmıştır. ${ }^{49}$ Defterimizde bu tip tımarlara rastlanılmamış, bunun yerine, bazı köyler hizmetleri karşılığı olarak vergiden muaf sayılarak bu hizmeti yerine getirmişlerdir. Osmanlı Devleti'nde bir tımar türü de saray için avcı kuş yetiştirmektir. Defterimizde bu tip tımarlar bazı köylere bırakılarak bu hizmet karşılığı vergiden muaf sayılmışlardır. Örneğin Tımışvar Muharrir-i Muharrem Bey'e gönderilen

\footnotetext{
${ }^{48}$ Ioan Hategan, Henrik Ottendorf Becstol Temesvarig, (1663), Editura Banatul Timişoara, 2006, s.97.

${ }^{49}$ Sosyalı Ali Çavuş Kanunnamesi, a.g.m., s. 74.
} 
hükümde vilayet-i mezbûre de bazı haymane reayadan şahinci yazılması hususunda emir verilmiştir. ${ }^{50}$

Tımışvar Sancağı'nda toplam dağıtılan dirliklere baktığımızda burada doğal olarak en büyük payı haslar almaktadır. ikinci sırada, Osmanlı Devleti bölgeyi kontrol edebilmek için askeri garnizonlar kurmuş, gelirlerin büyük bölümü de bu garnizonlarda görev yapan sipahi ve kale muhafızlarına ayrılmıştır.

Tablo 6: 1555-1556 Yılında Tımışvar Sancağı'nın Gelir Dağılımı

\begin{tabular}{|c|c|}
\hline Tımarın Türü & $\mathbf{1 5 5 5 - 1 5 5 6}$ Yılı \\
\hline Has & 2.117 .302 \\
\hline Zeâmet & 528.893 \\
\hline Tımar & 1.008 .497 \\
\hline Toplam & $\mathbf{3 . 6 5 4 . 4 6 2}$ \\
\hline
\end{tabular}

Tımışvar Sancağı'nın 1555/56 yılında toplam hasılı 3.654 .462 akçedir. Bu meblağın 2.117.302 akçesi has, 528.893 akçesi zeamet ve 1.008.497 akçesi tımar olarak tahsis edilmiştir. Toplam gelir dağılımı içerisinde haslar \%57,9'unu, tımar gelirleri \%27,5'ini, zeamet sahiplerine $\% 14,6^{\prime}$ lık bir pay sancağın gelirlerinden tahsis edilmiştir.

\section{Sonuç}

Osmanlı taşra teşkilatında Tımışvar olarak adlandırılan bölge, Kanuni Sultan Süleyman zamanında 1552 yılında Osmanlı hakimiyetine girdikten sonra Vilayet haline getirilerek 1718 yılında Habsburg hakimiyetine geçene kadar durumunu sürdürmüştür. Osmanlı idari taksimatında yer alan Tımışvar miri arazi rejiminin uygulandığı bölgelerdendi. 1554 yılında yapılan tahrirlerde Tımışvar Sancağı'nda sancak gelirlerinin önemli bir kısmı padişah haslarına ayrıldıktan sonra, geri kalan sancak gelirlerinin vilayetin yöneticisi olan beylerbeyi haslarına, zeametlere ve tımarlara ayrıldığı tımar icmal defterlerinden anlaşılmaktadır.

${ }^{50}$ Kitabet eden Muharrem'e 9 ramazan 975 tarihli hüküm, BOA, MD. 7, hüküm 195.

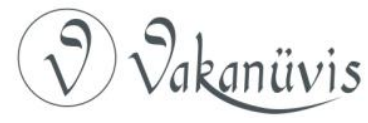




\section{Kaynakça}

\section{Arşiv Kaynakları}

BOA. TT. (Tapu Tahrir Defterleri Kataloğu), 290, 298, 674.

BOA. MD. (Mühimme Defterleri Kataloğu) Defter No: 6,7.

\section{Diğer Kaynaklar}

Acun, Fatma. "Klasik Dönem Eyalet İdare Tarzı Olarak Timar Sistemi ve Uygulaması", Türkler, Cilt 9, Ankara 2002. 899-908.

Afyoncu, Erhan ve Abdülkerim Özaydın. "Mîr-i Alem (Osmanlılar'da)", D.i.A., Cilt 30, İstanbul 2005. 123-125.

Agoston, Gabor. Osmanlı'da Savaş ve Serhad. İstanbul: Timaş, 2013.

Akdağ, Mustafa. Türkiye'nin iktisadi ve Içtimai Tarihi. İstanbul: Yapı Kredi, 2010.

Akgüzdüz, Ahmed. Osmanlı Kanunnameleri ve Hukuki Tahlilleri. V.Kitap, II. Kısım, İstanbul: 1992.

Barkan, Ö.Lütfi. “Timar", İslam Ansiklopedisi, C. XII/I, 1979. 286-333.

Bilge, Sadık Müfit, Osmanlı'nın Macaristanı, İstanbul: Kitabevi, 2010.

Fekete, Lajos. "Macaristan'da Türklerin Mülk Sistemi”, çev. M.Tayyib Gökbilgin, İstanbul Üniversitesi Tarih Dergisi, Sayı 16, İstanbul 1961. 25-42.

Fodor, Pal, "Das Wilajet von Temeschwar zur Zeit der osmanischen Eroberung", Südost-Forschungen, 55 (1996). 25-44.

Gökbilgin, M.Tayyib. “Kanuni Sultan Süleyman'ın Timar ve Zeamet Tevcihi ile IIIgili Fermanları", iü. Tarih Dergisi, Sayı 22, İstanbul 1967. 35-48.

Günalan, Rıfat. Osmanlı Imparatorluğunda Defterdarlık Teşkilatı ve Bürokrasisi. İstanbul: Kayıhan, 2010.

İnalcık, Halil. "Timar", DiA, C.41. İstanbul 2012. 168-173. ,"Eyalet", DiA, C.11, İstanbul 1995. 548-550.

Özcan, Abdulkadir, "Fatih'in Teşkilat Kanunnamesi ve Nizam-ı alem için Kardeş Katli Meselesi", TD, Sayı 33, İstanbul 1982. 7-56.

Peçevi İbrahim Efendi. Peçevi Tarihi, haz. Bekir Sıtkı Baysal. Ankara: Kültür Bakanlığı, 1981.

Sofyalı Ali Çavuş Kanunnamesi. Osmanlı İmparatorluğunda Toprak Tasarruf Sisteminin Hukuki ve Mali Müeyyede ve Mükellefiyetleri, haz. Midhat Sertoğlu, iü. Fen-edebiyat Yayınları, NO.26, İstanbul 1992

Şahin, İlhan. "Timar Sistemi Hakkında Bir Risale", iÜ. Tarih Dergisi, Sayı 32, İstanbul 1979. 905-935.

Üçok, Çoşkun. "Osmanlı Devleti Teşkilatından Tımarlar", Ankara Üniversitesi Hukuk Fakültesi Dergisi, C.2, S.1, Ankara 1944. 525-551.

Tabakoğlu, Ahmet. Türk iktisat Tarihi. İstanbul: Dergah, 1998.

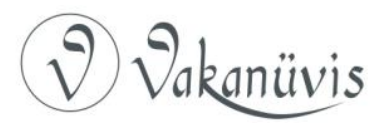

